HARMONY AND

COUNTERPOINT

Ritual Music in

Chinese Context 



\section{HARMONY AND}

\section{COUNTERPOINT}

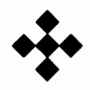

\section{Ritual Music in Chinese Context}

EDITED BY BELL YUNG,

EVELYN S. RAWSKI, AND RUBIE S. WATSON

STANFORD UNIVERSITY PRESS

Stanford, California 
Stanford University Press

Stanford, California

(C) 1996 by the Board of Trustees of the Leland Stanford Junior University

Printed in the United States of America

CIP data appear at the end of the book

Publication of this book was underwritten in part

by a grant from the Chiang Ching-kuo Foundation for International Scholarly Exchange 